\title{
RELASI GENDER DALAM KAJIAN ISLAM "THE TAO OF ISLAM, KARYA SACHIKO MURATA"
}

\author{
Atika Zuhrotus \\ Sufiyana \\ Dosen Universitas Islam \\ Malang (UNISMA)
}

\begin{abstract}
Listened more closely, Sachiko's cosmological and theological approach of murata flourished from the view of men and women, the word of Allah: "and everything we created in pairs". Couples who are often called dalm al-Qur'an that can be interpreted as a picture of the cosmos is the sky and earth. A number of verses imply that everything in the universe is covered by both of these. In this discussion, we can find the special feature of Sachiko Murata's thinking lies in the approach that uses cosmological and theological approach, followed by Chinese cosmology which focuses on the thinking of Chinese and Islamic philosophy which depicts the universe within the boundaries of Yin and Yang principles. In an easily digestible language, Sachiko murata attempts to analyze gender relations through cosmological theory in Islam, by emphasizing the concept of Tajalliyat Ibn 'Arabi, which is similar to Emotion's emancipation theory. In the Qur'an, there are 99 names of Allah that show these two attributes. He concludes that the Feminine Masculine mapping of gender differences of identity when associated with God as a source of human and natural existence, then every human being has masculine and feminism, as the phenomenon of day and night, darkness, and so on.

The product of his thinking about gender relations became clearer, when Sachiko murdered the argument in the form of an analogy of the creation of the heavens and the earth (male and female relationships such as the relationship of heaven and earth), the degree of men to women and in marriage, all of which came from reality cosmology. A woman in relation to a man is like Nature in relation to divine command, because woman is the locus for the existence of children. Nature in relation to the divine command is the locus of the embodiment for the entities of the physical bodies. Through the laws of nature they are born and from themselves they become manifest. There is no command without the laws of nature and there is no law of nature without command. Understanding the degree of men over women, men are superior to one level above women in terms of cosmological justification, not merely based on the text of the Qur'an. While the woman's degree is elevated when the position of women as the recipient of the activity of men, means women have the advantage over the uterus as a manifestation of the survival of natural reproduction and women are made alluring so that men give love, affection to women because women are part of men. Here is where God makes men and women equal in the case of Shari'a.
\end{abstract}

Keywords: Gender, Study of Islam. 


\section{PENDAHULUAN}

Konsep gender menjadi topik pembahasan dalam berbagai seminar, diskusi, maupun tulisan di seputar perubahan sosial dan pembangunan dunia ketiga. Di Indonesia, istilah gender lazim dipergunakan di Kantor Menteri Negara Peranan Wanita dengan ejaan "ender", dan diartikan sebagai interpretasi mental dan kultural terhadap perbedaan kelamin, yakni laki-laki dan perempuan. (Mufidah, 2010: 7-9).

Isu gender sesungguhnya telah masuk dalam pelataran diskursus akademik di Indonesia sejak tahun 90-an. Hingga sekarang, berarti telah memasuki paruh terakhir pada dekade kedua. Namun demikian, isu dan persoalan gender tampaknya belum menjadi perhatian penting bagi semua kalangan. Banyak orang menilai bahwa masyarakat Indonesia yang mayoritas beragama Islam menolak wacana yang dianggap berasal dari Barat tersebut. (Ummi Sumbulah, 2008: 1). Dalam dua dasa warsa terakhir ini kita menyaksikan suatu proses perubahanperubahan pradigma melalui perdebatan yang cukup panjang dalam gerakan fenimisme, yakni antara pemikiran yang telah lebih memfokuskan sistem dan stuktur masyarakat dan didasarkan "analisis gender". Analisis gender membantu memahami bahwa pokok persoalannya adalah sistem dan struktur yang tidak adil, dimana baik laki-laki maupun perempuan menjadi korban dan mengalami dehumanisasi karena ketidakadilan gender tersebut. Kaum perempuan mengalami dehumanisasi akibat ketidakadilan gender sementara kaum lelaki mengalami dehumanisai karena melanggengkan penindasan gender. Untuk memahami masalah kaum perempuan maka perlu dibedakan antara sex dan gender. (Handayani, 2006: 2-3)

Dari pemaparan di atas, akan membahas mengenai dua hal pokok, yaitu definisi gender, dan pemikiran Sachiko Murata mengenai relasi gender dalam kajian Islam yang ada dalam buku THE TAO OF ISLAM: KITAB RUJUKAN TENTANG RELASI GENDER DALAM KOSMOLOGI DAN TEOLOGI ISLAM, Diterjemahkan dari The Tao of Islam: A Sourcebook on Gender Relationship in Islamic Thought karya Sachiko Murata. 


\section{PEMBAHASAN}

\section{Wawasan Teoritik Gender}

Kata "gender" berasal dari bahasa Inggris, berarti jenis kelamin. (John Echols dan Hassan Shadily, 1983: 265). Gender yaitu perbedaan yang tampak pada laki-laki dan perempuan apabila dilihat dari nilai dan tingkah laku. Dalam Women's studies Encyclopedia dijelaskan bahwa gender adalah suatu konsep kultural, berupaya membuat perbedaan (distinction) dalam hal peran, perilaku, mentalitas, dan karekteristik emosional antara laki-laki dan perempuan yang berkembang dalam masyarakat. (Helen Tierney, 1991: 197).

Hilary M. Lips dalam bukunya yang terkenal Sex dan Gender: An Introduction mengartikan gender sebagai harapan-harapan budaya terhadap lakilaki dan perempuan (Kultural Expectations for Woman and Man). Misalnya perempuan dikenal dengan lemah lembut, cantik, emosional dan keibuan. Sementara laki-laki dianggap kuat, rasional, jantan dan perkasa. Ciri-ciri dan sifat itu merupakan sifat yang dapat dipertukarkan, misalnya ada laki-laki yang lemah lembut; ada perempuan yang kuat, rasional, dan perkasa. Perubahan ciri dan sifat itu dapat terjadi dari waktu ke waktu dan dari tempat ke tempat yang lain. (Hilary M. Lips, 1993: 4).

Julia Cleves Mosse mendefinisikan gender dengan seperangkat peran, yang seperti halnya kostum dan topeng di teater, menyampaikan kepada orang lain bahwa kita adalah feminism atau maskulin. Perangkat perilaku khusus ini yang mencakup penampilan, pakaian, sikap, kepribadian, bekerja di dalam dan di luar rumah tangga, sekaligus tanggung jawab keluarga dan sebgainya secara bersamasama memoleh "perang gender" masyarakat. (Julia Cleves Mosse, 2002: 2). Begitu pula Ahmad Baidlowi mengutip pendapat Ann Oskley, yang berpendapat bahwa gender adalah sifat dari laki-laki dan perempuan yang dikonstruksi secara sosial dan kultural, sehingga tidak identik dengan seks. (Ahmad Baidawi, 2001: 203).

Sedangkan hasil diskusi Nasarudin Umar dkk, gender diartikan semata-mata merujuk pada karakteristik-karakteristik sosial, seperti perbedaan dalam gaya rambut, pola pakaian, jenis pekerjaan dan aktifitas lain yang secara kultural dipelajari. (Nasarudin Umar, Suparman Syukur dkk., 2002: 3). 
Berdasarkan berbagai pemahaman di atas, gender secara umum dapat didefinisikan sebagai suatu konsep kultural yang membedakan antara laki-laki dan perempuan dipandang dari segi sosial dan budaya yang dapat berubah sesuai dengan perkembangan zaman. Dengan demikian relasi gender bukan merupakan akibat dari perbedaan biologis.

Dalam budaya patriarkal, perbedaan peran antara laki-laki-dan perempuan dipandang sebagai akibat dari perbedaan jenis kelamin. Tugas perempuan seperti memasak di dapur, berhias untuk suami dan mengasuh anak serta pekerjaan domestik lainnya merupakan konsekuensi dari jenis kelamin. Tugas domestik perempuan bersifat abadi sebagaimana keabadian identitas jenis kelamin yang melekat pada dirinya. Pemahaman ini berawal dari kerancuan paradigma tentang gender differentcer dan sex differences. Sesungguhnya, gender dan sex itu berbeda. Gender digunakan untuk mengidentifikasi perbedaan laki-laki dan perempuan dari aspek sosial dan budaya. Sementara perbedaan seks digunakan untuk mengidentifikasi perbedaan laki-laki dan perempuan secara anatomis dan biologis. (Lisa Luttle, 1986: 123)

\section{Biografi Sachiko Murata}

Sachiko Murata dilahirkan di Jepang, tahun 1943. Perkenalannya dengan Islam dimulai semasa menjadi mahasiswi yang tengah mempelajari hukum keluarga di Universitas Chiba di pinggiran kota Tokyo. Rasa keingintahuan Sachiko Murata tergugah ketika mengetahui bahwa hukum keluarga Islam membolehkan seorang pria mempunyai empat isteri sembari pada saat yang sama diharapkan bisa tetap mempertahankan kedamaian dan keharmonisannya sekaligus.

Setelah menyelesaikan studinya dan bekerja setahun di sebuah badan hukum di Tokyo, rasa keingintahuannya semakin menggebu terutama ketika seorang sahabatnya dari Iran menawarkan mengusahakan beasiswanya untuk mempelajari hukum Islam di Universitas Teheran, Iran. Segera Sachiko Murata tidak menyianyiakan kesempatan ini. tahun 1967 Sachiko Murata berangkat ke Iran untuk belajar di Universitas Teheran. Sebelum mempelajari lebih jauh tentang hukum Islam, dia memutuskan untuk memperdalam bahasa Persia selama tiga tahun. Tahun 1971, dia berhasil menyelesaikan disertasi PhD dalam bidang sastra Persia 
tentang peranan kaum wanita dalam Hayft Paykar, dengan mengkaji sebuah karya puisi yang ditulis oleh Nizhami.

Sachiko Murata tercatat sebagai seorang wanita non muslim pertama yang mendaftar masuk Fakultas Teologi dalam Program Yurispundensi (fiqh), dan berkesempatan secara langsung mempelajari hukum Islam dari beberapa otoritas terkemuka dibidangnya, diantaranya: Sayyid Hassan Iftikharzada Sabziwari, seorang ulama terdidik dalam bidang metodologi tradisional yang membantunya mengkaji beberapa teks tersulit dari Yurisprudensi (Fiqh dan prinsip-prinsip Yurisprudensi (Ushul Fiqh). Profesor Abu al-Qasim Gurji' serta Profesor Toshihiko Izutsu, pembimbingnya, sehingga Sachiko Murata berhasil menerjemahkan teks klasik abad ke-10 H / $16 \mathrm{M}$, tentang prinsip-prinsip Yurispundensi, Mu'allim al-Ushul ke dalam bahasa Jepang.

(http://www.stonybrook.edu/asianandam/murata_sachiko.html.)

Dalam waktu yang tidak terlalu lama, Sachiko Murata menyadari bahwa berbagai pra konsepsi dia tentang kedudukan wanita dalam Islam yang dipelajari orang-orang Jepang dari sumber-sumber Barat, sama sekali tidak berkaitan dengan realitas masyarakat Iran saat itu sebelum revolusi Iran terjadi. Sebagai seorang wanita pertama dalam program tersebut, dia selalu diperlakukan dengan penuh sopan dan hormat oleh dosen dan para mahasiswa. Ada kesan mendalam selama dia mengambil studi di Teheran seperti yang diutarakannya:

"Selama bertahun-tahun bergaul dan bekerjasama dengan para sarjana seperti Gurji, Iftikharzada dan lainnya, saya tidak pernah merasakan diperlakukan secara khusus hanya karena saya seorang wanita. Mereka memperdebatkan berbagai macam persoalan dengan saya sebagaimana yang mereka lakukan dengan rekan-rekan mereka sendiri. Kadang-kadang mereka berusaha meyakinkan saya bahwa merekalah yang benar, dan sesekali saya juga menyakinkan mereka bahwa sayalah yang benar. seringkali kami ngotot dan bersikukuh dengan pendapat kami masingmasing, dengan tetap menghormati satu sama lain. Pada tingkat ilmu, gender bukan masalah. Hanya saja, manakala seorang pria mengunjungi seseorang bersama istrinya, ada aturan-aturan tertentu yang perlu diperhatikan ." (Sachiko Murata, 1996: 26)

Di Iran Sachiko Murata mulai mempelajari tradisi sufisme yang disebutnya sebagai tradisi kearifan (hikmah) secara serius dan sungguhsungguh, tentang beberapa kajian yuridis. Selama beberapa tahun beliau mengikuti beberapa kuliah professor Izutzu tentang Fushus al-Hikam karya Ibn al-'Arabi dan kuliah yang 
disampaikan oleh Sayyed Hosein Nasr mengenai karya besar klasik Persia yang menganut mazhab ibn al-`Arabi, Syarhi Ghulsyani-I raz. Salah satu kajian yang menjadi kenangan berkesan selama tahun-tahun studinya adalah ketika dia menelaah dan mengkaji ajaran cemerlang Jalal al-Din Huma'i, yang kehadirannya cukup meyakinkan Sachiko Murata bahwa Islam memiliki tradisi spiritual yang dalam dan hidup. Tahun 1975, Sachiko Murata menyelesaikan tesis M.A-nya di Fakultas Teologi dengan topik pernikahan sementara (nikah mut'ah) berikut relevansi sosialnya.

Semenjak perjumpaannya dengan berbagai manifestasi peradaban Islam klasik, baik dalam bidang seni, arsitektur, puisi, ajaran-ajaran hukum, adatkebiasaan dan pandangan dunia menyeluruh. Sachiko Murata merasa bahwa semua itu mempunyai kedekatan yang erat degan latar belakang ketimurannya. Pada tahun 1977, wlaupun studinya di Teheran sempat terputus karena revolusi social yang terjadi di Iran, dia memutuskan untuk menulis disertasi Ph.D yang membandingkan ajaran-ajaran Islam dan Kong $\mathrm{Hu} \mathrm{Cu}$ tentang keluarga, tapi revolusi Iran menyebabkan riset tersebut berhenti. Selama masa tersebut, bersama professor Izutsu, dia mempelajari I Ching, yakni tentang ajaran-ajaran dasar filsafat Cina, dan ini membuatnya semakin akrab dengan kedalaman-kedalaman filosofis eksplisit dalam pemikiran Cina.

Tahun 1983, Sachiko Murata bergabung dengan Fakultas Agama di Stony Brook dan diminta untuk mengajar mata kuliah "spiritualitas feminine dalam agama-agama Dunia”. Tugas terberat yang harus dihadapinya adalah mengubah pandangan kuno tentang kedudukan wanita dalam Islam yang hampir tidak pernah berubah. Prasangka bahwa wanita Timur, khususnya wanita muslim, merupakan kaum yang paling tertindas dan tertekan di muka bumi tampaknya telah berakar kuat di benak para mahasiswa dan koleganya. Walaupun Islam mungkin mempunyai sisi-sisi menarik untuk dikemukakan, namun sama sekali bukan aspek peran wanitanya dalam masyarakat. Untuk itulah, beliau menggunakan pendekatan tak langsung, menjelaskan Islam bukan dari konteks Barat, dengan segala asumsinya mengenai seksualitas dan peran gender yang tersirat tapi melalui perspektif timur jauh. Sachiko Murata mempunyai alasan kuat, ajaran-ajaran dasar filsafat cina sudah dikenal para pembaca terdidik Barat. Popularitas I Ching serta kehadiran symbol Yin dan Yang menyebabkan tak banyak orang yang mesti 
diberitahu bahwa pemikiran Cina sangat menekankan prinsip harmoni dan keseimbangan antara dua peran eksistensi. Sebaliknya, kosmologi Islam secara praktis tak dikenal, karena tak banyak cendikiawan Muslim yang mencurahkan perhatian pada pandangan yang lebih dalam atau makna dibalik institusi Islam.

Melalui pendekatan yang dipilihnya tersebut, menjelang akhir diskusi, ketika melihat peranan ideal yang dimainkan kaum wanita dalam masyarakat yang sesuai dengan ajaran-ajaran spiritual Islam, sachiko Murata menemukan para mahasiswanya tidak lagi sulit menghargai fakta bahwa peranan gender dalam Islam bukan tidak bertujuan sama sekali dan bukan dimotivasi oleh kepentingankepentingan politis. Adapun karya karya dari Sachiko Murata yang telah dihasilkan sampai kurun waktu sekarang. Beberapa diantaranya ditulis dalam bahasa Inggris, namun tidak sedikit yang ditulis dalam bahasa ibunya, bahasa Jepang.

1. Buku-Buku Sachiko Murata yang sudah dipublikasikan, antara lain:

a. Izdi waj-i muwaqqat, Teheran Hamdani, 1978, 97 pp;

b. Isuramu hooriran Jestsu (principle of Islamic Law, translation with introduction and commentary of ma'alim al-usiul by Shaykh hasan, Tokyo: Iwanami (Islamic Classiics, general editor T. Isutzu, 1985, 564 pp.

c. Temporary marriage in Islamic Law, London: Muhammadi Trust, 1987, 73 pp, reprinted qum: Ansariyan Publications, 1991.

d. The Tao of Islam: A Sourcebook on Gender Relationship in Islamic Thought, Albany: SUNY Press, 1992, 410pp. Indonesian translation by Ratna Megawangi, Bandung, Mizan, 1995.

e. Sachiko Murata and William C. Chittick, The Vision of Islam, New York: Paragon, 1994, 39+368 pp. Pakistan edition: Lahore: Suhail Academy, 1998.

f. Chinese Gleams of Sufi Light: Wang Tai-yu's Great Learning of The Pure and Real liu Chih's Displaying The Concealment of The Real Realm, Albany: SUNY Press, in production (2000). 
2. Artikel-artikel yang telah ditulisnya, antara lain:

a. Shiaha isuramu no tokushoku ("characteristic of Shi'ite Islam), Isuramu Pawa no Kenkyu, vol. 2, Tokyo: Chutoo Choosakai, 1982, pp. 22-34.

b. Akund Korasani: His importance in Osul, Encylopedia Iranica, London: Routdge and Kegan Paul, Vol. 1, 1984, pp. 734-35.

c. Anshari, Syaikh, Ibid.., vol. 2, 1985, pp. 102-103.

d. Angels on Islmic spirituality: Foundation (vol. 19 of world Spirituality" A Encyclopedia History of the Religions Quest), New York: Crossroad, 1987, pp. 324-344.

e. Masculline / feminine Complementaryin Islamic spiritual Psychology, Islamic Quartely 33, 1989, pp. 165-187.

f. The Tao of Islamic, Sufi 5, 1990, pp. 17-21.

g. Myteries of Marriage: Notes on Sufi Text, the Legacy of Mrdieval Persian Sufism, edited by Leornard.

h. Kawaranu Hito, (The unchanging Personality).

i. Isuramu to Josei (Islam and women).

j. Witnessing the Rose: Ya'qub Sarfi on the vision of God in Women.

k. Ta'lim-1 Islam dar Maghribzamin (Teaching Islam in the West). (www.adsense-success-guide.com/Sachiko_Murata.html.)

\section{Konsep Pemikiran Sachiko Murata tentang Relasi Gender}

\section{Argumen Kesetaraan Gender Sachiko Murata}

Sachiko murata mencoba menganalisis relasi gender melalui teori Kosmologi dan Teologi dalam Islam (mirip dengan teori kosmologi Cina yakni Yin dan Yang) degan mengedepankan konsep Tajalliyat Ibn 'Arabi, yang mirip dengan teori Emansipasinya Plotenus yaitu: mengungkapkan apa makna Kesatuan, makna Dualitas yang berasal dari Kesatuan dan dari dualitas menjadi kesatuan kembali. Agar pemahaman lebih mudah dipahami, kita dapat mengklasifikasikan dalam poin-poin berikut ini:

a. Argumen Kosmologi

Konsep dasar dalam pendekatan kosmos atau alam (penjelasan dari alam semesta) yang diejawantahkan Sachiko Murata, adalah dengan memunculkan statement bahwa "semua yang diciptakan Tuhan di alam semesta ini serba 
berpasang-pasangan". Pandangan dasar yang beliau gunakan, berpangkal dari firman Allah dalam surat adz-Dzariat ayat 49:

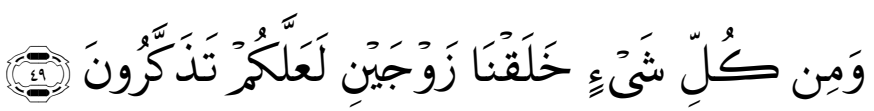

Dalam pemahaman ayat inilah, Murata mengaplikasikannya pada penciptaan alam yang serba berpasang-pasangan, seperti diciptakannya langit tntu ada bumi, ada pria-ada wanita, ada siang-ada malam, ada baik-ada buruk, dan segala hal macamnya. Namun, dalam kosmos atau alam tak satu pun dapat dikatakan lengkap dan sempurna tanpa yang lainnya. Semua yang diciptakan Tuhan mempunyai kelebihan dan kekurangannya masing-masing. Atas dasar ciptaan Tuhan yang mempunyai kelebihan dan kekurangan inilah, memunculkan sebuah relasi untuk saling melengkapi dan saling membutuhkan antara satu dengan yang lainnya, misalnya: langit dan bumi, pasangan yang sering disebutsebut dalam al-Qur'an dimana makna dari kata langit adalah yang lebih tinggi, paling atas dan merupakan bagian dari pada sesuatu sedangkan bumi adalah menghasilkan, membuahkan bersikap lembut ketika diinjak dan diduduki. Begitu juga manusia yang diciptakan berjenis kelamin pria dan wanita. Pria mempunyai kelebihan yang tidak dimiliki oleh wanita, wanita mempunyai kelebihan yang tidak dimiliki oleh pria. Ketika pria dan wanita mempunyai kelebihan, tentu masing-masing memiliki kekurangan. Untuk menyempurnakan antara kekurangan dan kelebihan tersebut, harus ada relasi saling melengkapi dan saling membutuhkan diantara keduanya, sehingga muncul kesejajaran tanpa adnya ketimpangan yang menunjukkan superior dan inperior. Konsep inilah yang digunakan Sachiko Murata untuk menjelaskan relasi gender.

Pendekatan yang dipakai untuk menjelaskan relasi gender, kadang-kadang terpengaruh oleh pemikiran Cina ajaran Taoisme (kosmologi alam) dalam kerangka "Yin" dan Yang" yang memang menjadi latar belakang kulturnya, yakni Asia Timur. Dalam kosmologi Cina menjelaskan alam semesta dalam batasanbatasan kerangka "Yin" dan "Yang" merangkul satu sama lain dalam keselarasan dan keterpaduan. "Yin" dan "Yang" sebagai gerakan perubahan karena itu seluruh alam semesta berubah setiap saat. Yin menginterpretasikan segala sesuatu yang bersifat lembut, pasif, dan interior, ia berwarna gelap, bertemperatur dingin dan 
bergerak ke bawah dimana unsur Yin adalah cair (yang selalu ditegaskan dalam Thaotching, air selalu mencari daratan yang lebih rendah). Yin berkaitan dengan immaterial bumi dan nama-nama kendahan seperi: Jamal, Luthf, Rahmah. Sedangkan Yang menginterpretasikan sesuatu yang bersifat kuasa, akitif, ia berwarna putih, tinggi, dan meluas, Yang juga mengacu pada immateri dan energi dimana unsur Yang adalah api dan panas (nama-nama Keagungan Jamal, Qahr, Ghadab).

Taoisme sering memperlakukan Yin lebih baik dari Yang, namun keduanya pada akhirnya termanifestasi melalui lingkaran kehidupan. Pemisahan yang sangat luas karena hampir dalam banyak Yin selalu ada kadar Yang, dan dalam banyak Yang terdapat beberapa Yin. Alam pemikiran Cina mengakui peran suci dan kewahyuan dunia ini, karena dunia ini meruapakan lokus dimana sifat Tao menunjukkan realitasnya. Tao berbicara tentang harmoni antara antara langit dan bumi dan keseimbangan sempurna diantara seluruh kekuatan yang menggerakkan dunia supranaturalnya dan lazimnya, tetapi sering dilupakan bahwa al-Qur'an penuh dengan bahsan tentang tanda-tanda Allah yang terhampar di dunia ini, Ide keseimbangan langit dan bumi mempunyai kedudukan sentral dalam pesan alQur'an, sebagaimana dikenal dalam banyak tradisi Islam. (Sachiko Murata, 2003).

b. Argumen Teologi

Dalam tradisi intelektual, berbicara tentang kosmos sama artinya dengan berbicara tentang Tuhan. Pemikiran tentang Tuhan berpusat pada nama-nama atau sifat-sifat ilahi yang diwahyukan dalam al-Qur'an.

Masing-masing dari dua perspektif dasar itu (keterbandingan dan keserupaan) dikaitkan dengan nama-nama sifat-sifat tertentu. Keterbandingan Allah seperti Maha Kuasa, Maha Tak Terjangkau, Maha Besar, Maha Agung, Maha Pencipta, Maha Tinggi, Maha Raja, Maha Pemarah, Maha Pembalas, Maha Penghancur, Maha Pemusnah, dan Maha Penyiksa. Hadis menyebut kesemuanya ini sebagai nama-nama Keagungan (jalal), atau Hebat (qahr), atau adil ('adl), serta Murka (ghadhab). Dalam konteks ini nama-nama tersebut semuanya termasuk dalam "nama-nama Yang” karena menekankan kebesaran, keagungan, kekuasaan, kontrol dan maskulinitas. Sebaliknya, keserupaan Allah mengingatkan kepada kita pada nama-nama Maha Indah, Maha Dekat, Maha Pengasih, Maha Penyayang, Maha Kasih, Maha Lembut, Maha Pengampun, Maha Pemaaf, Maha 
Pemberi Hidup, Maha Pemberi Kekayaan, dan Maha Pemberi. Semuanya dikenal dengan nama-nama keindahan (jamal), atau kelembutan (luthf), atau anugerah (fadhl), serta rahmat (rahmah). Kesemuanya ini adalah "nama-nama Yin" karena menekankan kepasrahan kepada kehendak dan keinginan pihak lain, kelembutan, penerimaan dan reseptivitas. (Sachiko Murata, 1996: 31).

Dalam teori itu dikemukakan bahwa pada mulanya adalah "Tao" atau Tuhan (zat yang Esa menunjukkan pada makna kesatuan). "Tao" menciptakan kosmos ini dengan dua kualitas atau dualitas yaitu "Kualitas Feminim" (yin) dan "Kualitas Maskulin" (yang). Tuhan memiliki sifat Maskulin dan Feminim yang dipancarkan pada setiap manusia, baik lak-laki maupun perempuan yang dimanifestasikan melalui 99 nama Allah (Asmaulhusna). Pemetaan Maskulin Feminim pada perbedaan gender Identity jika dihubungkan dengan Tuhan sebagai sumber keberadaan manusia dan alam, maka setiap manusia memiliki sifat Maskulin dan Feminim. Artinya laki-laki memliki sifat-sifat Maskulin (yang) dan perempuan memiliki sifat-sifat Feminim (yin), sebagimana fenomena siang-malam, gelapterang, langit dan bumi dan seterusnya (makna dualitas). Tetapi, setelah kita memahami bahwa laki-laki adalah manifestasi dari yang dan perempuan dari yin, seolah laki-laki mempunyai derajat lebih tinggi atas perempuan (terbentuk atas konstruk budaya yang menjadikan laki-laki lebih maskulin dan perempuan lebih feminim). Padahal, kualitas dua-duanya secara potensial adalah sama, sama-sama terbentuk dari ciptaan sifat maskulin dan feminim Tuhan. Oleh karena itu, harus memunculkan relasi yang harmonis dengan tidak memuliakan salah satu dari keduanya, tetapi memuliakan keharmonisannya dengan menganggap sama derajat pria dan wanita. Relasi derajat yang sama tersebut berdasarkan kualitas manusia, sama dihadapan Tuhan, yang membedakannya adalah tingkat ketaqwaan dan pengakuan ke-Esa-an terhadap Allah, karena tidak ada Tuhan selain Allah (tauhid).

Sachiko Murata menjelaskan tentang esensi dari realitas Tuhan. Tuhan adalah Zat Maha Esa, Tuhan adalah realitas Tunggal. Sesuatu selain Zat adalah ciptaannya yang disebut dengan kosmos (al-'Alam) dimaknai sebagai "segala sesuatu selain Allah". Pengertian lain menyatakan, Tuhan secara tak terbatas berada jauh di luar kosmos. Disini istilah teologisnya adalah tanzih yang bermakna: "menyatakan Allah sebagai tak bisa dibandingkan". Dari sudut 
pandang ini Allah benar-benar tak bisa dijangkau oleh makhluk-makhlukNya. (http://www.humanevol.com). Al-Qur'an menyebutkan Allah dengan ungkapan:

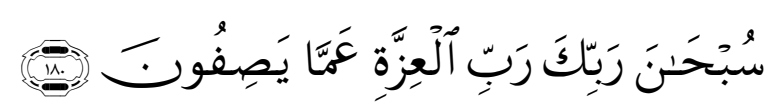

Atau dalam ungkapan yang lebih sederhana:

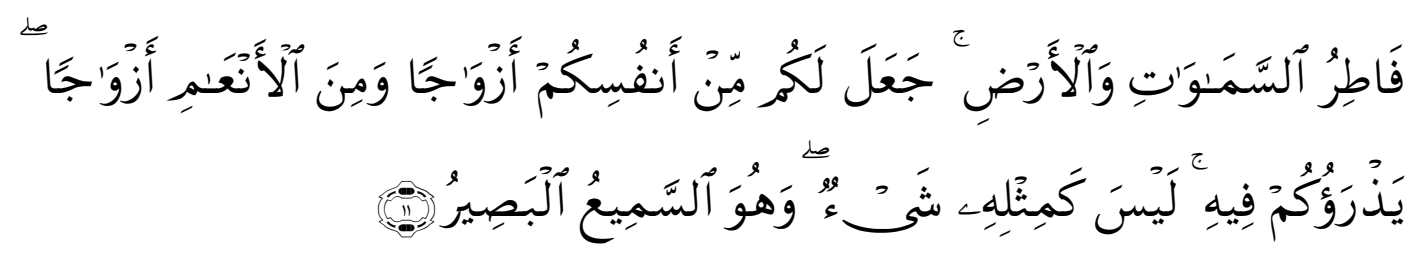

Untuk membuktikan bahwa realitas Tuhan itu ada, maka Tuhan menciptakan alam atau kosmos sebagai bukti atau tanda keberadaanya dan manusia sebagai subjek yang mengakui keberadaannya. Istilah ini Sachiko Murata memberikan analogi yang dikenal dengan tiga realitas dasar yakni: Allah, kosmos atau makrokosmos, manusia atau mikrokosmos. Kita bisa menggambarkan ketiganya ini sebagai tiga sudut dari sebuah segitiga, yang secara khusus menarik adalah hubungan yang terjalin diantara ketiga sudut itu. Allah yang berada di puncak dan merupakan sumber yang menciptakan kedua sudut yang ada di bawah, karena baik makrokosmos dan mikrokosmos adalah realitas-realitas derivatif. Setiap sudut bisa dikaji dalam hubungannya dengan satu atau dua sudut lainnya.

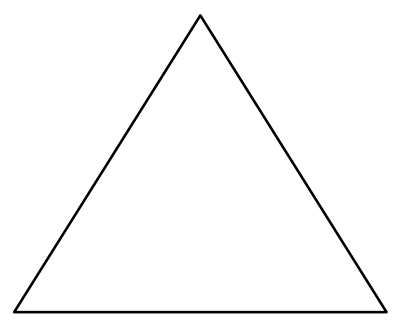

Dipuncak, sumbu vertikal menggambarkan dibentuk oleh perbedaan antara esensi ilahi dan sifat-sifat ilahi, sementara sumbu horizontal mencerminkan berbagai hubungan antara nama-nama ilahi komplementer, seperti yang Maha Memuliakan dan Maha Menghinakan atau yang Maha Menghidupkan dan Maha Mematikan. Anggapan bahwa alam dan manusia adalah makro dan mikrokosmos ini terjadi ketika keduanya diandaikan berasal dari diri Tuhan. Permasalahan ini berimplikasi pada kesimpulan bahwa ada jejak Tuhan di dalam diri manusia (anfus) dan di dalam diri alam (afak). Kaena itu jika ingin menemukan Tuhan atau 
kebenaran atau arah kehidupan ini, alam dan diri manusia menyimpan sejumlah peta rahasia rencana arah kehidupan ini.

Argumen teologis Sachiko Murata lebih mudah dimengerti dengan menjelaskan bahwa: semula zat yang ada (realitas Tuhan sebagai yang Khaliq) adalah satu. Sang Khaliq kemudian menciptakan kosmos beserta seluruh esensi yang melengakpinya secara berpasangan-pasangan. Makhluk-makhluk ciptaan Tuhan mempunyai tugas dan kewenangan berbeda yang terbentuk dalam satu tatanan kosmos. Manusia, bumi, langit, galaksi, cuaca, dan lain-lainnya saling melengkapi menjadi satu tatanan kosmos yang tidak dapat dipisahkan. Apabila satu dari bagian tersebut menghilangkan maka akan timpang dan tidak menjadi tatanan kosmos (saling melengkapi satu sama lain) semua makhluk tersebut mempunyai kesetaraan dan kesejajaran yang sama dihadapan Tuhan sebagai ciptaanNya (kembali pada Yang Esa).

Dari uraian di atas, kita dapat mengambil benang merah yang menunjukkan bahwa Sachiko Murata menguraikan perbedaan kosmologi dan teologi tersebut secara sistematis dengan menjelaskan apa makna Kesatuan, dan makna Dualitas yang berasal dari Kesatuan. Dengan menggunakan nama-nama Allah (Asmaulhusna). Beliau membagi nama-nama Keagungan atau yang disebut sebagai Kualitas Maskulin, dan nama-nama Keindahan atau yang disebut Kualitas Feminim. Dari korespondensi Dualitas tersebut, muncul pluralitas, keterpisahan yang dijelaskan dalam proses penciptaan jagad raya sebagai Makrokosmos, dan manusia sebagai Mikrokosmos. Kemudian Dualitas akan menjadi kesatuan kembali, ketika ia menguraikan makna dan tujuan Dualitas yang ditampakkan melalui adanya lawan kebaikan dari segala sesuatu (misalnya: langit-bumi, atasbawah, Tuhan-manusia, raja-abadi, cahaya-gelap, baik-buruk, feminim-maskulin) dengan mengembalikan makna Dualitas kepada makna yang satu atau Tauhid. (Ratna Megawangi, 2003: 9-10)

Pendekatan semacam ini, memiliki persamaan dengan kosmologi Cina yang melukiskan alam semesta dalam batasan-batasan kerangka Yin dan Yang, yang bisa dipahami sebagi prinsip-prinsip eksistensi yang bersifa aktif dan reseptif atau pria dan wanita. Yin dan Yang merangkul satu sama lain dalam keselarasan, dan perpaduan keduanya menghasilkan sepuluh ribu hal, yakni segala sesuatu yang ada. Simbol terkenal Tai Chi, atau Tao, melukiskan Yin dan Yang sebagai gerakan 
dan perubahan yang konstan. Dalam fenomena tersebut, hubungan antara Yin dan Yang terus menerus berubah. Karena itu, seluruh alam semesta berubah setiap saat, bagaikan sungai yang mengalir. Yin dan Yang adalah prinsip-prinsip perubahan dan simbol bagi seluruh gerakan di alam semesta. Ketika matahari terbit, rembulan pun tenggelam. Kala musim tiba, musim dingin pun beranjak pergi. Eksistensi berarti perubahan harmonis dengan berpijak pada Tao. Jika harmoni anatara Yin dan Yang hilang, maka alam semesta akan berhenti mengalir dan tak ada sesuatu apapun. (http://www.sufism.ru/eng/txts).

\section{Relasi Gender dalam Perspektif Sachiko Murata}

a. Penciptaan Langit dan Bumi

Al-Qur'an memberikan pandangan dalam Islam tentang pria dan wanita sebagai sebuah komplementaritas berbagai fungsi.

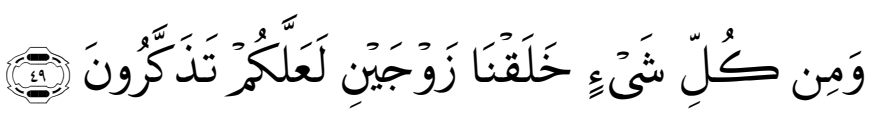

Dalam pemikiran kosmologi Islam, alam semeta dipahami sebagai sebuah keseimbangan atau ekuilibrium yang dibangun berdasarkan relasi polar yang harmonis antara pasangan-pasangan yang membentuk segala sesuatu.

Jika segala sesuatu diciptakan berpasang-pasangan, "segala sesuatu selain Tuhan" pastilah berpasangan, yaitu terbuat dari dua realitas yang berbeda namun saling melengkapi. Beberapa pasangan dapat diartikan sebagai yang mencakup segala sesuatu, istilah yang digunakan untuk mengacu pada akar-akar dari semua benda ciptaan seperti: bentuk dan materi, cahaya dan kegelapan, penegasan dan penyangkalan, dan seterusnya. Pasangan yang sering disebut dalam al-Qur'an yang dapat ditafsirkan sebagai gambaran keseluruhan kosmos adalah langit dan bumi. Sejumlah ayat mengisyaratkan bahwa segala sesuatu di alam raya dicakup oleh keduanya ini. Setidaknya dapat dikatakan bahwa langit dan bumi disebutkan sebagai dua titik acuan dasar di dunia ini. Seperti dalam al-Qur'an:

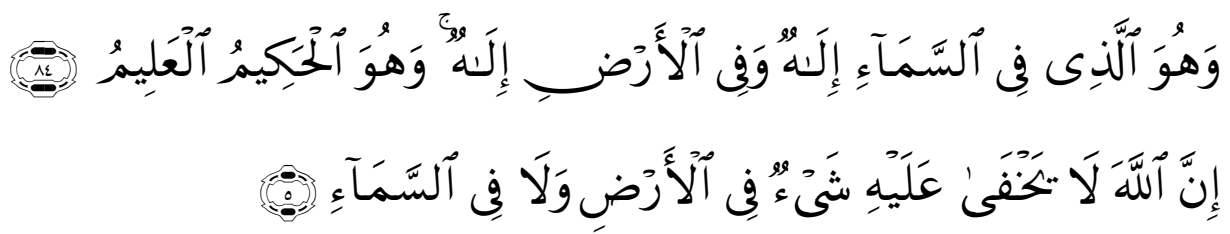




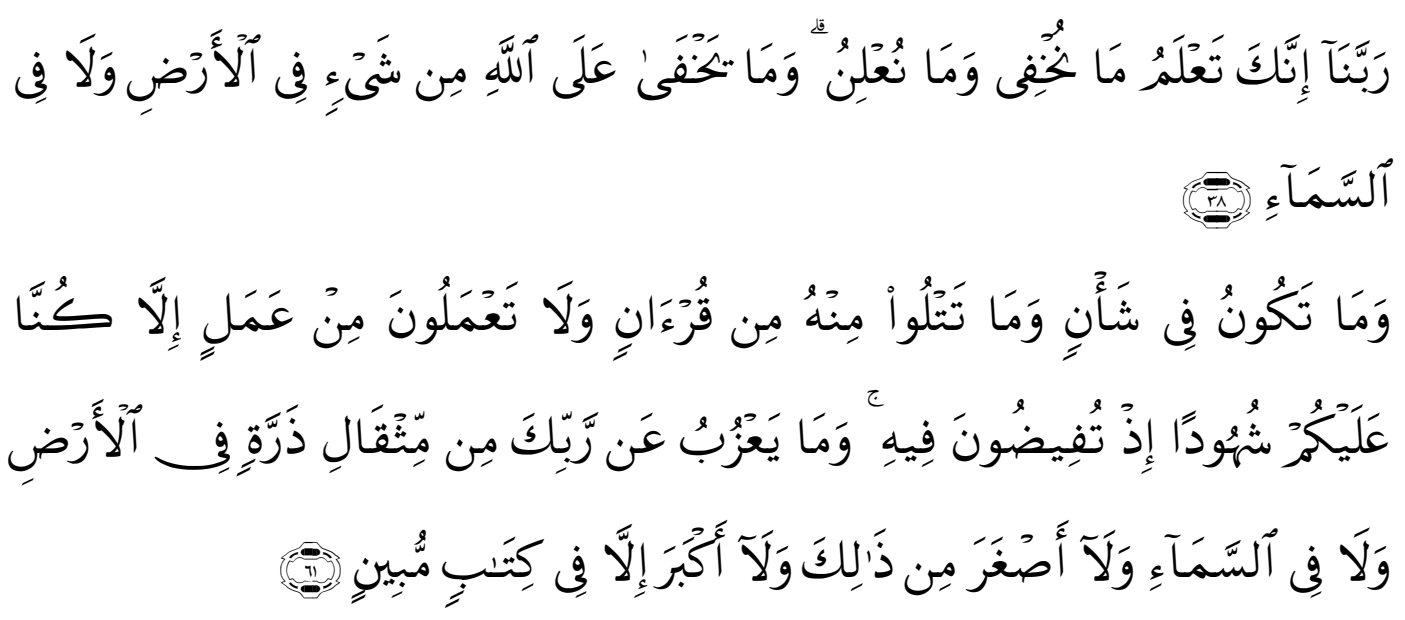

Harus dicatat bahwa makna dasar dari kata sama' (langit) adalah "yang lebih tinggi, lebih atas, atau paling tinggi, paling atas", bagian dari segala sesuatu itu juga dinamakan dalam arti angkasa, awan, hujan dan karunia. Sebaliknya, akar verbal dari kata $\operatorname{ardh}$ (bumi) berarti berusaha dan menghasilkan; membuahkan hasil; bersikap lembut ketika diinjak-injak dan diduduki; bersikap merendah, menyerah, secara alamiah terpanggil untuk berbuat baik. Ardh adalah "tempat tinggal manusia”, tanah, lantai; segala sesuatu yang rendah. (Sachiko Murata, 1996: 167).

Langit dan bumi mewakili dimensi vertikal dan statis dari kosmos. Karena itu mereka berkebalikan dengan pasangan "dunia ini” (al-dunya) dan akhirat (alAkhirah), yang mewakili hubngan horizontal dan dinamis antara situasi kita sekarang dalam kehidupan ini dan situasi masa depan kita setelah kematian. Hubungan statis antara langit dan bumi akan tetap kuat hingga Hari Akhir, namun selanjutnya ia akan hidup dalam bentuk yang telah berubah.

Penggambaran al-Qur'an tentang penciptaan langit dan bumi mengingatkan pada suatu tindakan primordial yang menimbulkan dualitas dan menetapkan “pasangan-pasangan” sebagai unsur-unsur dasar eksistensi. Al-Qur'an menyatakan secara jelas bahwa langit dan bumi ada secara bersama-sama dalam keadaan yang tak terbedakan atau bersatu sebelum penciptaan.

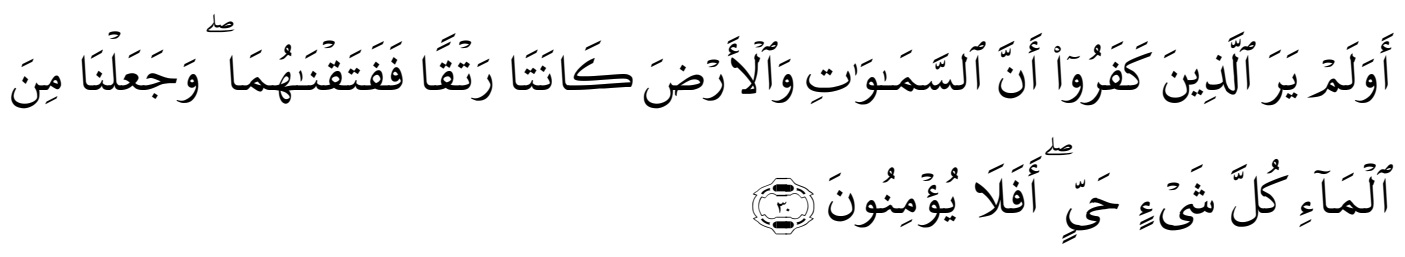

Padanan mikrokosmik bagi pemisahan langit dan bumi adalah penciptaan adam dan hawa dari satu jiwa. Kedua jiwa ini berasal dari jiwa tunggal primordial 
yang kemudian menjadi "pasangan" (zawjan) manusia pertama. "Pasangan" (zawj) dalam al-Qur'an secara harfiah berarti salah satu dari dua anggota pasangan.

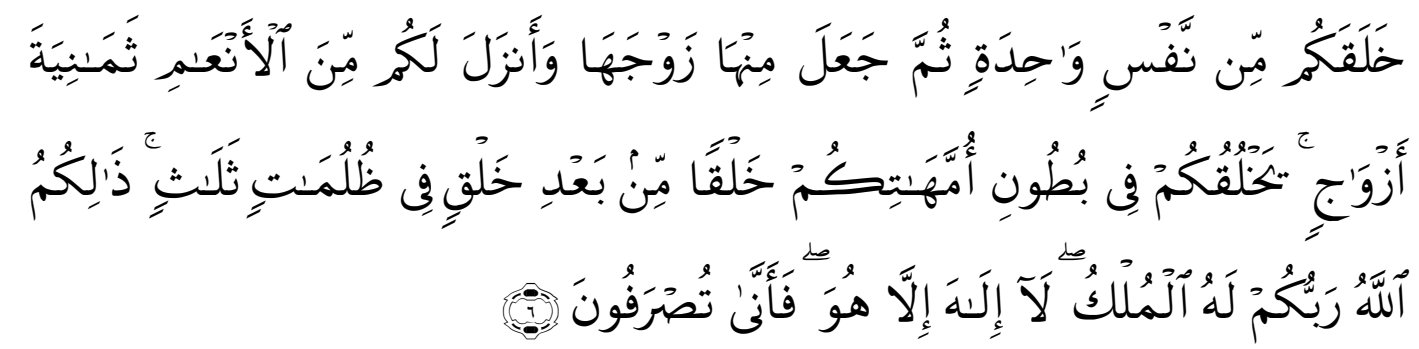

Sachiko Murata menyatakan bahwa hubungan laki-laki dan perempuan adalah hubungan yang saling membutuhkan, bukan hubungan atas bawah maupun dikuasai ataupun menguasai, tapi layaknya hubungan langit dan bumi. Laki-laki diibaratkan langit dan perempuan diibaratkan bumi. Langit membutuhkan tempat untuk menurunkan hujan, dan bumi membutuhkan air untuk menumbuhkan tumbuhan. Hubungan antara langit dan bumi adalah hubungan antara Yang dan Yin, pria dan wanita, suami dan istri. Dari konsep inilah kita bisa mengikis anggapan superioritas kaum laki-laki atas perempuan. Dalam al-Qur'an dinyatakan bahwa kedudukan derajat laki-laki dan perempuan adalah sama dan bahwa kaum laki-laki maupun wanita yang mengerjakan amal baik akan mendapat ganjaran yang sama. Yang membedakan manusia di mata Allah SWT hanyalah kualitas takwa. (Sachiko Murata, 1996: 165)

\section{b. Perkawinan}

Dalam hal ini Sachiko Murata menjelaskan tentang relasi gender yang terlihat dari proses tanda-tanda perkawinan alam yang dimulai dari perkawinan ilahi. Tuhan sebagai Zat Yang Esa melakukan perkawinan dengan: Zat Esa sebagai Ayah dan Ibunya adalah benda-benda yang non eksisten. Ketika Tuhan menciptakan dengan perintah "Kun", maka Tuhan melakukan perkawinan dengan benda-benda yang non eksisten yang melahirkan ciptaannya "Fayakun". (An-Nahl (16): 40.) Seperti yang sudah diterangkan di atas dalam kosmos reproduksi berlangsung sebagai berikut: langit menjatuhkan air hujan dan bumi menerima air itu. "ia menggelembung" yaitu menjadi hamil "dan menumbuhkan tanamantanaman beraneka ragam”. (Al-Hajj (22): 5.)

Dari sinilah kita dapat mengetahui hubungan antara Tuhan dan makrokosmos (konsep dari tiga sudut segitiga yakni Allah, Makrokosmos, dan 
Mikrokosmos). Kaitannya dengan perkawinan antara manusia dengan manusia atau wilayah mikrokosmos, kita perlu mempertimbangkan ajaran-ajaran Islam yang ada kaitannya dengan hubungan antara pria dan wanita dan kemudian melihat konteks mengenai Tuhan, makrokosmos dan mikrokosmos. Pada satu tingkat, Islam memandang hubungan seksual sebagai bagian yang alamiah dan normal dari ciptaan Tuhan yang baik. Dalam perkawinan antara pria dan wanita diberikan hak yang sama untuk menjalankan ibadah itu. Dengan menjalankan ibadah pria dan wanita akan mendapatkan pahala atau ganjaran yang sama.

Dalam perspektif transendental, Tuhan itu berjarak dari hambanya. Ia Maha Tidak Dikenal dan tidak dapat dipahami karena Kemahaagungan-Nya. Namun dari sudut pandang imanensi, Tuhan menunjukkan diri-Nya dalam segala hal sesuatu dan dapat dialami melalui segala sesuatu. Seluruh kosmos dan segala sesuatu yanga ada di dalamnya merupakan pengungkapan diri Tuhan. Dan lokus terbesar dari pengalaman pengungkapan diri Tuhan adalah melalui pengalaman seksual dalam perkawinan manusia.

Setiap manusia yang berada di permukaan bumi ini pada umumnya selalu menginginkan kebahagiaan, dan berusaha agar kebahagiaan itu tetap menjadi milikinya. Tetapi kebahagiaan itu tidak dapat dicapai dengan mudah tanpa mematuhi peraturan-peratutan yang telah digariskan agama. Salah satu jalan untuk mencapai kebahagiaan itu dengan jalan perkawinan. (Firdaweri, 1989: 1)

Pernikahan menjadi sunah dalam perjalanan setiap hamba-Nya. Dalam keindahan perkawinan, manusia dikuasai oleh kekuatan akan kesenangan, dan dengan jalan itu dapat mencicipi kebahagiaan dari hubungan surgawi dengan Tuhan. Kesenangan ini mewujudkan kekuatan Tuhan. Kesenangan ini mewujudkan kekuatan Tuhan (qahr), yang biasanya disejajarkan dengan kelembutan-Nya (luthf). Hubungan antara keduanya adalah hubungan antara kebesaran dan keindahan, kemurkaan dan belas kasih. Sebagimana Islam yang menuntut kepasarahan kepada Tuhan sebagai syarat kesempurnaan seorang manusia, maka dalam perkawinan penyerahan diri total pada kekuatan tidak menuntut pada pemisahan dan kemurkaan, melainkan pada kegembiraan yang tiada tara. Walau begitu, ada juga orang-orang yang menganggap perkawinan adalah nafsu hewani. Berkebalikan dengan para kekasih Allah, yang memandang 
perkawinan sebagai suatu yang terpuji dan sangat surgawi. (Sachiko Murata, 1996: 251).

Dalam Islam, hubungan seksual adalah bentuk kesenangan terbesar di surga. Para Nabi dan kekasih Tuhan telah mengalami kesenangan surgawi ini di kehidupan dunia. Perkawinan manusia di dunia adalah cetak biru perkawinan orang-orang saleh di surga. Bahkan, melahirkan anak-anak dalam aktivitas seksual bukan tujuan utama. Tujuan utama dari aktivitas seksual adalah kesenangan, jika kebetulan anak-anak dilahirkan sebagai akibatnya, tidak menjadi masalah. Pada hakikatnya, wanita terwujud dari pria, maka dia seperti menjadi bagian darinya. Wanita terpisah dan terwujud dalam bentuk feminim. Maka, kerinduan Nabi kepada mereka merupakan jenis kerinduan dari keseluruhan kepada bagiannya.

Sampai di titik ini, timbul pertanyaan mengapa kita bisa mencintai perempuan?

Ibn Al-'Arabi mengatakan bahwa kaum wanita adalah bagian dari Rasul, yang paling sempurna di antara semua pria. Maka, "Kaum wanita dibuat memikat baginya" maka dia akan merindukan mereka, hanya karena keseluruhan merindukan bagian-bagiannya”. Bagi Ibn Al-“Arabi, kerinduan pria kepada wanita merupakan cermin kerinduan Tuhan kepada manusia. Akar kerinduan Ilahi kepada manusia terdapat dalam firman-Nya:

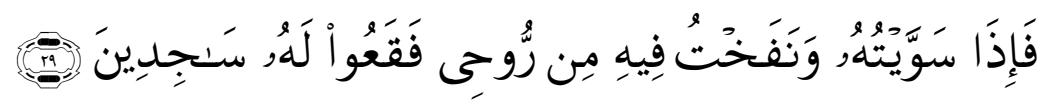

Kalau digambarkan, jalinan cinta itu membentuk segitiga tiga cinta, masingmasing sudut menunjukkan hubungan yang tak dapat dipisah-pisahkan antara Allah, Pria, dan Wanita. Allah SWT adalah eksistensi cinta tertinggi. Kemudian, Allah menciptakan Adam dari ruh-Nya yang ditiupkan. Adam adalah bagian yang merindukan keseluruhan (Allah SWT). Kemudian, Allah menciptakan Hawa sebagai bagian dari Adam. Maka, Hawa pun merindukan Adam sebagai bagian merindukan keseluruhan. Adam merindukan Hawa sebagaimana keseluruhan merindukan bagian. Wanita menjadi manifestasi Allah yang akan membawa kesempurnaan pengenalan pada Allah SWT jika keduanya bersatu. 
c. Derajat Pria Atas wanita

Sachiko Murata mengawali penjelasan mengenai derajat pria atas wanita dengan mengungkapkan "Kaum pria satu derajat lebih tinggi dari pada mereka" dalam surat al-Baqarah ayat 228:

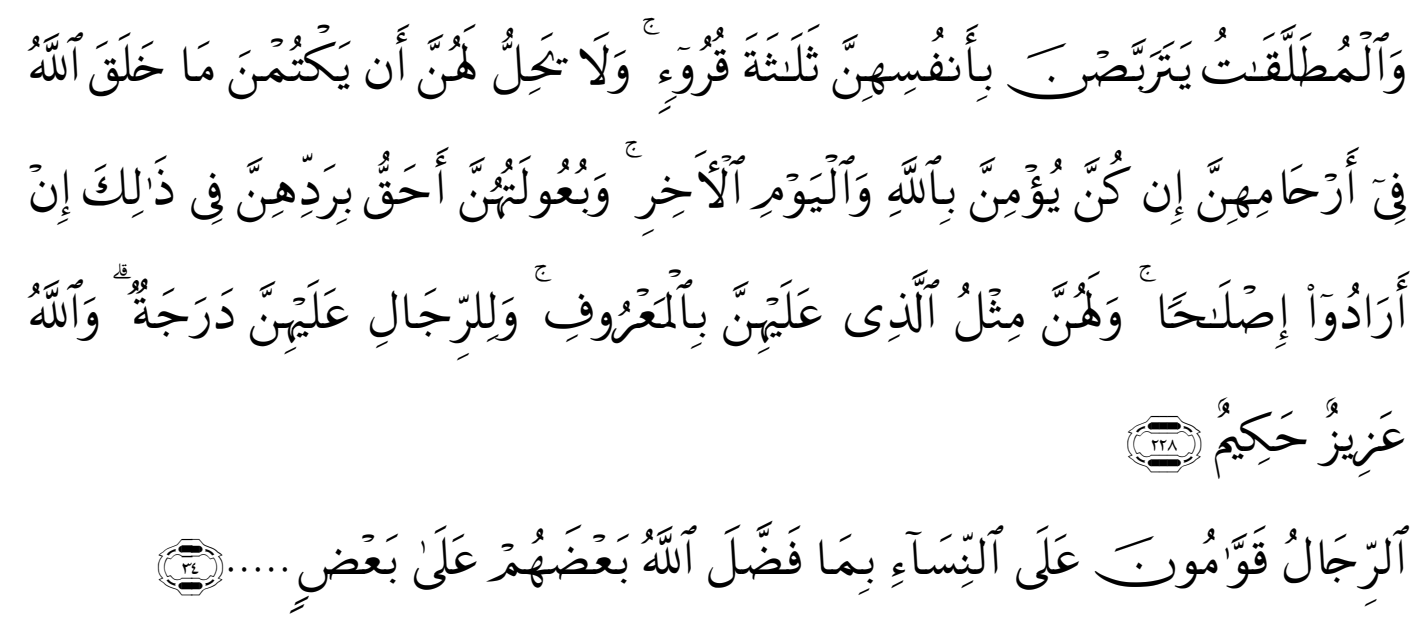

Banyak lagi ayat al-Qur'an dan hadis yang mengimplikasikan hal serupa yang mencakup hukum waris, kesaksian, kualitas akal dan agama antara pria dan wanita. Begitu pula ada anggapan bahwa sumber dari penafsiran "negatif" tentang perempuan adalah pada proses penciptaan Adam dan Hawa. Beberapa ayat alQur'an dan hadis mengatakan bahwa kaum perempuan diciptakan dari dan untuk pria. Bagi para feminis, mengimplikasikan bahwa seolah-olah perempuan adalah makhluk kedua (secondary creation) dan pria adalah makhluk utama. Misalnya dalam dua ayat al-Qur'an:

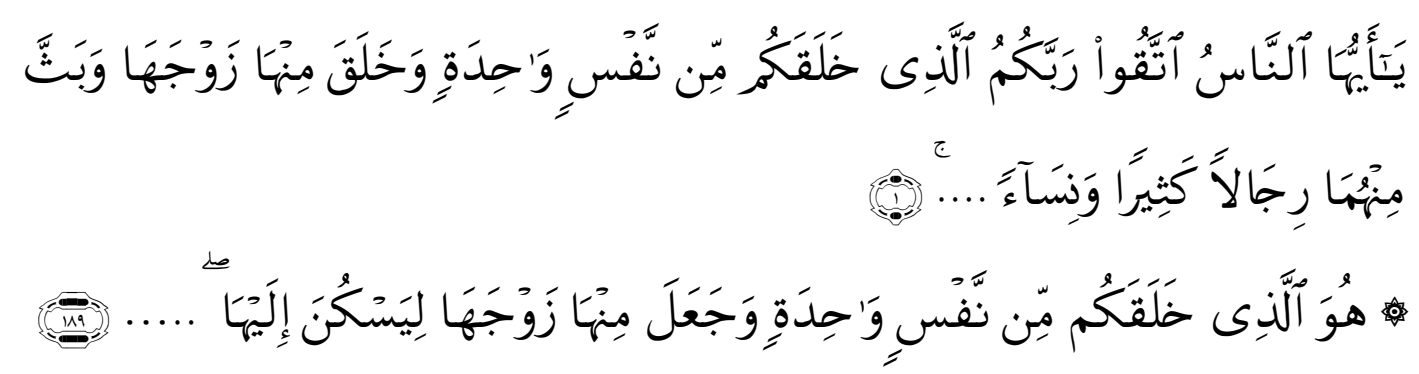

Dalam penjelasannya yang detail Sachiko Murata mengutip dari beberapa tokoh untuk membantu mengulas beberapa teks mengenai nash pria atas wanita, hingga Sachiko Murata memberikan penilaian bahwa "pria memang mempunyai derajat satu tingkat dibanding wanita", dengan alasan perkataan-perkataan semacam itu jelas dimaksudkan untuk menekankan makna penting dari ikatan perkawinan sebagai pondasi umat, juga menetapkan hal-hal tertentu yang tidak dapat diubah dalam hubungannya suami/istri. (Sachiko Murata, 1996: 235). 
Ada hal menarik yang perlu digaris bawahi bahwa, Sachiko Murata membalikkan penilaiannya tentang kedudukan pria yang mempunyai derajat satu tingkat lebih tinggi atas wanita. Hal ini berkaitan dengan analisisnya dengan menggunakan pendekatan kosmologi bahwa kesadaran akan kelemahan seseorang, ketidakmampuan dan posisi Yin dalam hubungan dengan yang Nyata merupakan keadaan dari penghambaan ('ubudiyah). Sebagaimana dikemukakan sebelumnya, menjadi hamba merupakan hubungan manusia yang sudah sepantasnya dengan Tuhan, suatu persyaratan yang diperlukan untuk mengaktualkan sifat-sifat Yang yang berkaitan dengan kekhalifaan. Dalam hal ini Sachiko Murata ingin mengoreksi mereka yang mengira bahwa wanita lebih rendah dibanding dengan pria dalam kemungkinan-kemungkinan pencapaian spiritual mereka. Wanita mempunyai pencapaian-pencapaian tertentu yang tidak dapat diraih kaum pria, seperti ungkapan Sachiko Murata yang mengutip pendapat Ibn 'Arabi dalam tulisannya. (Sachiko Murata, 1996: 238-239).

Kaum wanita sama dengan kaum pria dalam semua tingkat, bahkan sebagai Qutub. Hendaknya kamu tidak membiarkan dirimu terselubung oleh kata-kata dari Rasulullah. "Suatu bangsa yang menyerahkan pengurusan atau permasalahan mereka kepada seorang wanita tidak akan pernah berjaya". Kami sedang membicarakan tentang kekuasaan yang diberikan oleh Tuhan, bukan kekuasaan yang diberikan oleh rakyat. Jika satu-satunya hal yang telah sampai pada kita menyangkut soal ini adalah kata-kata Nabi, "kaum wanita adalah padanan kaum pria (kedudukan, tingkat atau atribut) juga dapat dimiliki oleh setiap wanita yang dikehendaki Tuhan, sebagaimana hal itu dapat dimiliki oleh setiap pria yang dikehendaki Tuhan.

Tidakkah kamu perhatikan kebijaksanaan Tuhan dalam kelebihan yang telah Dia berikan kepada wanita atas pria dalam namanya? Kepada manusia berjenis kelamin pria, Dia menyebut mar' dan kepada yang wanita Dia menyebut mar'ah; jadi Dia menambahkan sebuah "ah" atau "at" dalam bentuk konsepsi pada nama mar' yang diberikan kepada pria. Maka wanita mempunyai satu tingkat di atas pria dalam keadan ini, suatu tingkat yang tidak dimiliki oleh pria, bertentangan dengan tingkat yang diberikan kepada kaum pria dalam ayat, "kaum pria mempunyai satu tingkat lebih tinggi dari pada mereka" (QS. 2:228). Maka Tuhan 
menutup kesenjangan itu (berkaitan dengan ayat tersebut) dengan tambahan ini dalam mar'ah. (Sachiko Murata, 1996: 245-246).

Pemahaman Ibn 'Arabi dalam hal ini dengan mengambil sudut pandang mengenai suatu kesimpulan yang layak bagi sifat itu. Namun dalam analisis terakhir, kita memasuki faktor-faktor yang tidak dapat diperhitungkan dalam bentuk ilahi, yang mendorong pada ketidakterbatasan. Di sini Tuhan melakukan apa yang Dia inginkan, dalam hal itu tidak ada perbedaan antara kaum pria dan wanita. Dalam satu sisi, kaum wanita diunggulkan dengan mitos penciptaan Hawa yang teripta dari tulang rusuk Adam. Karena Hawa adalah cabang dari Adam, Tuhan menempatkan cinta dan kasih sayang diantara keduanya. Ternyata mencintai perempuan itu sesuatu yang suci dan agung. Sachiko Murata mengatakan bahwa menyaksikan atau merenungkan Tuhan dalam diri wanita merupakan jenis kesaksian paling sempurna yang diberikan manusia. Bagaimana kita tidak mencintai perempuan, kalau manusia termulia pun begitu mencintai perempuan. Dalam sebuah hadis, Rasulullah Muhammad SAW berkata, "Tiga hal dari dunia ini dibuat memikat padaku: kaum wanita, parfum dan kesejukan mataku ketika shalat”. Menurut Sachiko, cinta yang dirasakan Nabi terhadap kaum wanita adalah bagi semua pria sebab Nabi adalah contoh kesempurnaan yang harus ditiru. Seperti kita tahu, Nabi takkan melakukan suatu perbuatan yang dapat menjauhkan dirinya dari Allah. Karena itulah perempuan dibuat memikat bagi Nabi. Kecintaan pada perempuan itu ilahiah, karena perbuatan ini adalah warisan Nabi dan kecintaan ilahi. Seorang pencari Tuhan, untuk dapat menyingkap makna kedekatan dengan Tuhan harus melalui jalan ini, mencintai perempuan. Tanpa ini, perjalanan pencari Tuhan akan menemui titik buntu. Di sini berarti, para wanita membantu para pencari Tuhan untuk memahami hakikat penyingkapan. (Sachiko Murata, 1996: 246).

\section{KESIMPULAN}

Kalau disimak lebih cermat, pendekatan kosmologi dan teologi Sachiko murata berkembang dari pandangan tentang pria da wanita, yakni firman Allah SWT: "dan segala sesuatu kami ciptakan berpasang-pasangan". Pasangan yang sering disebut dalm al-Qur'an yang dapat ditafsirkan sebagai gambaran kosmos adalah langit dan bumi. Sejumlah ayat mengisyaratkan bahwa segala sesuatu di 
alam raya dicakup oleh keduanya ini. Setidaknya dapat dikatakan bahwa langit dan bumi disebutkan sebagai dua titik acuan dasar di dunia ini.

Pada pembahasan ini, kita dapat menemukan ciri khusus dari pemikiran Sachiko murata terletak pada pendekatannta yang menggunkan pendekatan kosmologi dan teologi, diikuti pula kosmologi Cina yang menitikberatkan pada pemikiran filsafat Cina dan Islam yang melukiskan alam semesta dalam batasan prinsip Yin dan Yang. Dalam bahasa yang mudah dicerna, Sachiko murata mencoba menganalisis relasi gender melalui teori kosmologi dalam Islam, dengan mengedepankan konsep Tajalliyat Ibn 'Arabi, yang mirip dengan teori emansipasinya Plotinus. Dalam al-Qur'an disebutkan 99 nama Allah yang menunjukkan kedua sifat ini. Ia berkesimpulan bahwa pemetaan Maskulin Feminim pada perbedaan gender identity jika dihubungkan dengan Tuhan sebgai sumber keberadaan manusia dan alam, maka setiap manusia memiliki sifat maskulin dan feminism, sebagaimana fenomena siang-malam, gelap-terang, dan seterusnya.

Produk pemikirannya tentang relasi gender semakin jelas dapat dipahami, ketika Sachiko murata memberikan argumentasi dalam bentuk analogi mengenai mengenai panciptaan langit dan bumi (hubungan pria dan wanita seperti hubungan langit dan bumi), derajat pria atas wanita dan dalam perihal perkawinan, yang semuanya berasal dari realitas kosmologi. Seorang wanita dalam hubungannya dengan seorang pria adalah seperti Alam dalam hubungannya dengan perintah Ilahi, sebab wanita adalah lokus bagi eksistensi anak-anak. Alam dalam hubungannya dengan perintah Ilahi adalah lokus dari berwujudan bagi entitasentitas dari badan-badan jasmani. Melalui hukum alam mereka dilahirkan dan dari dirinya mereka menjadi terwujud. Tidak ada perintah tanpa hukum alam dan tidak ada hukum alam tanpa perintah.

Pemahaman derajat pria atas wanita, pria lebih unggul satu tingkat atas wanita dalam hal pembenaran kosmologi, bukan semata-mata berdasarkan teks alQur'an. Sedangkan wanita derajatnya terangkat ketika posisi wanita sebagai penerima aktivitas dari pria, artinya wanita mempunyai keunggulan lebih engan diberinya rahim sebagai manifestasi kelangsungan reproduksi alam dan wanita dibuat memikat agar pria memberikan rasa cinta, kasih sayang kepada wanita 
karena wanita adalah bagian dari pria. Disinilah letak Tuhan membuat kaum pria dan wanita setara dalam hal Syariat. 


\section{DAFTAR PUSTAKA}

Al-Qur'an dan Terjemahannya.

Baidawi, Ahmad. Gerakan Feminisme dalam Islam. Jurnal Penelitian Agama (Yogyakarta: Pustaka Penelitian UIN Sunan Kalijaga). 2001.

Cleves Mosse, Julia. Gender dan Pembangunan, alih bahasa: Hartian Silawati, (Yogyakarta: Pustaka Pelajar dan Rifka Annisa). 2002.

Echols, John dan Hassan Shadily. Kamus Inggris-Indonesia. (Jakarta: Gramedia). 1983.

Firdaweri. Hukum Islam Tentang Fasakh Perkawinan Karena Ketidakmampuan Suami Menunaikan Kewajibannya. (Jakarta: Pesona Ilmu Jaya). 1989.

Handayani, Trisakti dan Sugiarti. Konsep dan Teknik Penelitian Gender. Malang: UMM Press). 2006.

Helen Tierney. Women's Studies Encyclopedia. (New York: Green Wood Press). 1991.

Luttle, Lisa. Encylopedia of Feminism. (New York: Facts On File Publication). 1986.

Mufidah. Gender di Pesantren Salaf. Why Not...?. (Malang: UIN-Maliki Press). 2010. 2004.

. Paradigma Gender (Edisi Revisi). (Malang: Bayu Media Publishing).

Murata, Sachiko. Kitab Rujukan tentang Relasi Gender dalam Kosmologi dan Teologi Islam. Diterjemahkan dari The Tao of Islam: A. Source book on Gender Relationship in Islamic Thought, Penerjemah Rahmani Astuti dan M.S. Nasrullah. (Bandung: Mizan). 1996.

Kearifan Sufi dan Cina. Penerjemah: Susilo Adi. (Yogyakarta: Kreasi Wacana). 2003.

M. Lips, Hilary. Sex \& Gender: An Introduction. (California: Myfield Publishing Company). 1993.

Sumbulah, Ummi. Spektum Gender. (Malang: UIN Malang Press). 2008.

Umar, Nasarudin dan Suparman Syukur dkk. Bias Gender dalam Pemahaman Islam. (Yogyakarta: Gema Media). 2002.

http://www.stonybrook.edu/asianandam/murata_sachiko.html. 
http://www.humanevol.com

http://www.sufism.ru/eng/txts

www.adsense-success-guide.com/Sachiko_Murata.html. 